\title{
Spontaneous Autoimmune Reactions against Pancreatic Islets in Mouse Strains with Generalized Autoimmune Disease
}

\author{
H. Kolb ${ }^{1}$, G. Freytag ${ }^{3}$, U. Kiesel ${ }^{1}$, and V. Kolb-Bachofen ${ }^{2}$ \\ ${ }^{1}$ Diabetes Research Institute and ${ }^{2}$ Institute of Biophysics and Electron Microscopy, University of Düsseldorf, Düsseldorf, \\ and ${ }^{3}$ Institute of Pathology, University of Münster, Münster, FRG
}

Summary. The spontaneously autoimmune mouse strains $\mathrm{NZB}, \mathrm{NZB} \times \mathrm{NZW}, \mathrm{MRL}$ and $\mathrm{BXSB}$ have been examined for signs of autoimmune reactions against islet cells. Between 15 and 55 animals of each strain were tested. Infiltrates of lymphocytes and fibroblasts into pancreatic islets were found in more than $80 \%$ of NZB mice, in about $50 \%$ of MRL and NZB $\times$ NZW mice, and in less than $20 \%$ of BXSB mice. Infiltrates were not found in the exocrine portion of pancrea. All NZB mice had abnormal glucose tolerance. In the three other strains between 20 and $50 \%$ of animals had abnormal glucose tolerance. All mice had fasting normoglycaemia. The lesions in NZB mice were studied in more detail. It was found by ultrastructural analysis that in young mice pancreatic infiltrates consisted of lymphocytes and fibroblasts. Single lymphocytes were also seen outside the main infiltration area. After 2 to 5 months of age another type of infiltrate, consisting of lymphocytes and macrophages was observed. B-cell destruction by lymphocytes was apparent in both young and adult NZB mice. It is concluded that cellular autoimmune reactions against pancreatic islets may occur spontaneously as a consequence of immunological disorders in NZB, NZB $\times$ NZW and MRL mice.

Key words: Insulitis, abnormal glucose tolerance, NZB mice, autoimmune mouse strains, cellular autoimmunity, diabetes mellitus.

The aetiology of insulin dependent diabetes has been studied in recent years with the help of experimental animal models using chemicals or viruses as diabetogenic agents [1-3]. More recently, a strain of rats spontaneously developing insulin-dependent diabetes has been described [4].
We have studied the possible existence of mouse strains spontaneously developing signs of autoimmune reactions against pancreatic islets. For this purpose 4 mouse strains with immunological disorders leading to lupus-like autoimmune diseases have been investigated. The strains NZB and NZB $\times$ NZW have been used for many years as a model for generalized human autoimmune disease [5]. The strains MRL and BXSB [6] have been discovered recently. Mice of the latter strains are also characterized by lymphoproliferative disorders and a lupuslike autoimmune disease [6].

\section{Materials and Methods}

\section{Mouse Strains}

$\mathrm{NZB} / \mathrm{CrBomf}$ mice of 2-10 weeks of age, NZB $\times \mathrm{NZW} / \mathrm{Bomf}$ mice of 6-10 weeks of age and BALB/c/A/Bom mice of 8 weeks of age were purchased. (Gl. Bomholtgard Ltd., Ry, Danmark). NZB/BINJ, MRL/Mp-lpr/lpr $\left(\mathrm{H}-2^{\mathrm{b}}\right)$ and BXSB $\left(\mathrm{H}-2^{\mathrm{k}}\right)$ mice were bought (Jackson Laboratories, Bar Harbor, Maine, U.S.A.) at 8-16 weeks of age. Mice received food and water ad libitum. All animals appeared to be healthy and of normal weight. None of them died spontaneously during the course of experiments.

\section{Histology}

Animals were exsanguinated after pentobarbitose anaesthesia $(250 \mathrm{mg} / \mathrm{kg}$ body weight) and the pancreas removed. Fixation of pancrea was in Bouin solution and the tissue embedded in paraffin. Sections $(5 \mu \mathrm{m})$ covering the head and tail of the organ were stained with hematoxylin-eosin, PAS and Giemsa for routine investigation. Of each pancreas at least 10 islets selected at random from all regions of the pancreas were analysed. Pieces of liver, heart, kidney and lungs were fixed in formalin, embedded in paraffin, and stained with hematoxylin-eosin.

For electron microscopy pancrea were cut into small cubes, fixed for $1 \mathrm{~h}$ in a solution containing $0.1 \mathrm{~mol} / 1$ cacodylate-HCL buffer, $0.15 \mathrm{~mol} / \mathrm{l}$ sucrose and $1.25 \mathrm{~g} / 100 \mathrm{ml}$ glutaraldehyde. Speci- 
Table 1. Prevalence of insulitis in five strains of mice. At least 10 islets per animal were screened (from all parts of the pancreas). The observation of 3 to 6 lymphocytes in at least $20 \%$ of islet sections was classified as weak insulitis, more than 6 lymphocytes as strong insulitis. Insulitis was never observed in $100 \%$ of islet sections but only in $25-50 \%$ of sections

\begin{tabular}{|c|c|c|c|c|c|c|}
\hline \multirow[t]{2}{*}{ Mouse strain } & \multirow[t]{2}{*}{ Age (weeks) } & \multirow[t]{2}{*}{ Sex } & \multicolumn{3}{|c|}{ Number of animals } & \multirow[t]{2}{*}{$\%$ Insulitis } \\
\hline & & & tested & $\begin{array}{l}\text { with strong } \\
\text { insulitis }\end{array}$ & $\begin{array}{l}\text { with weak } \\
\text { insulitis }\end{array}$ & \\
\hline \multirow[t]{4}{*}{$\mathrm{NZB}$} & $2-6$ & male & 13 & 2 & 10 & 92 \\
\hline & $2-6$ & female & 14 & 4 & 8 & 86 \\
\hline & $10-26$ & male & 14 & 6 & 6 & 86 \\
\hline & $10-26$ & female & 14 & 8 & 4 & 86 \\
\hline \multirow[t]{4}{*}{$\mathrm{NZB} \times \mathrm{NZW}$} & $5-6$ & male & 7 & 1 & 2 & 43 \\
\hline & $5-6$ & female & 5 & 0 & 1 & 20 \\
\hline & 23 & male & 5 & 0 & 2 & 40 \\
\hline & 23 & female & 5 & 0 & 2 & 40 \\
\hline \multirow[t]{2}{*}{ MRL } & $10-15$ & male & 8 & 1 & 2 & 38 \\
\hline & $10-15$ & female & 7 & 1 & 3 & 57 \\
\hline \multirow[t]{2}{*}{ BXSB } & $8-20$ & male & 13 & 0 & 2 & 15 \\
\hline & $8-20$ & female & 14 & 0 & 1 & 7 \\
\hline \multirow[t]{2}{*}{ BALB } & $8-16$ & male & 20 & 0 & 2 & 10 \\
\hline & $8-16$ & female & 20 & 0 & 1 & 5 \\
\hline
\end{tabular}
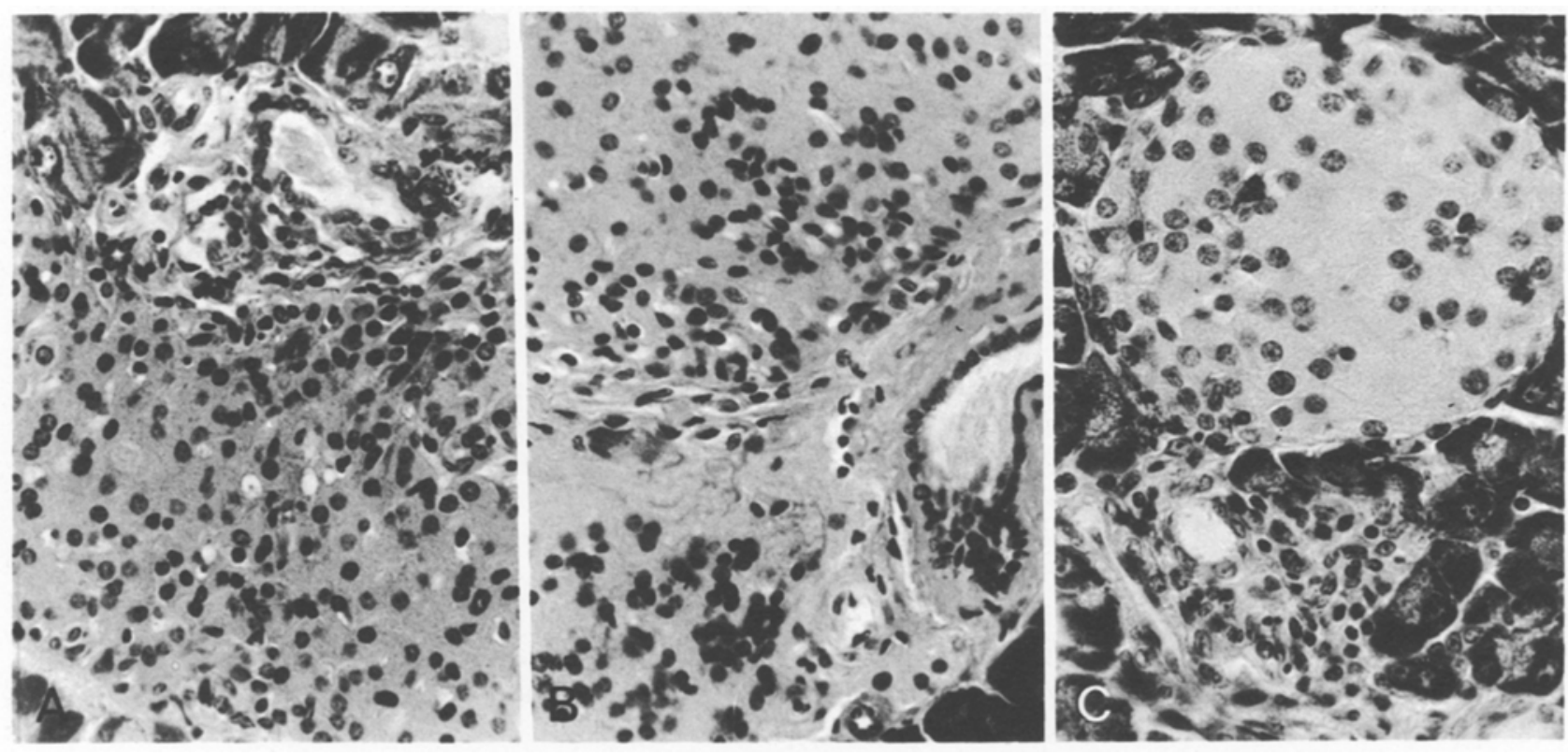

Fig. 1A-C. Pancreatic morphology in NZB, NZB $\times$ NZW and MRL mice. A Pancreatic section of a NZB/BINJ mouse, 6 weeks of age. Round cell infiltrates are seen at the ductular pole of the islet (hematoxylin-eosin, $\times 250$ ) B Pancreatic section of a NZB $\times$ NZW mouse, 23 weeks of age. Cellular infiltrates are localized in the ductular area (hematoxylin-eosin, $\times 250$ ). C Pancreatic section of a MRL mouse, 15 weeks of age. Infiltrates are predominantly periductular (hematoxylin-eosin, $\times 300$ )

men were postfixed in the same solution containing $1.0 \mathrm{~g} / 100 \mathrm{ml}$ $\mathrm{OsO}_{4}$ instead of glutaraldehyde. The cubes were dehydrated with ethanol and embedded in resin. For the rapid localization of islets $1.5 \mu \mathrm{m}$ sections were examined under the light microscope prior to ultrathin sectioning and electron microscopic investigation.

\section{Glucose Tolerance Test}

The test was performed with non-fasting animals 2 to 3 days prior to their sacrifice between 0900 and $1100 \mathrm{~h}$. Each mouse received $0.014 \mathrm{~mol}$ glucose $/ \mathrm{kg}$ body weight IP. Blood samples were drawn at 0,30 and $60 \mathrm{~min}$ from the retro-orbital sinus. Blood glucose was determined by the GOD-period method (Boehringer, Mannheim, W.-Germany) in a Technicon Autoanalyzer.

\section{Immunofluorescence Test}

Sera were tested for the presence of islet cell antibodies on frozen cut sections of pancrea from NZB and BALB/c mice, following the method of Bottazzo et al. [7]. Islet cell surface antibodies were determined on isolated islet cells as described by Kromann et al. [8]. For positive control experiments an islet cell antiserum raised in rabbits was used. 


\section{Results}

Pancreatic sections from NZB, NZB $\times$ NZW, MRL, $\mathrm{BXSB}$ and $\mathrm{BALB}$ mice of various ages were screened for pathologial changes of the islets (Table 1). Round cell infiltrates of the islets of Langerhans were recorded in the majority of NZB mice independent of age and sex. A lower incidence of insulitis was noted in MRL and NZB $\times$ NZW mice and almost no pathological changes could be found in BXSB mice (Table 1). For comparison data of a normal strain $(B A L B / c)$ are included. BALB/c mice are of the same $\mathrm{H}-2$ haplotype as NZB mice.

Figure 1 shows the type of insulitis found predominantly in NZB $\times N Z W, M R L$ and young NZB mice. In NZB mice clusters of mononuclear cells were found at the pole of islets adjacent to small ducts (Fig. 1 A). Fibrosis was a prominent feature. A similar localization of infiltrating cells was found in $\mathrm{NZB} \times \mathrm{NZW}$ and MRL mice (Fig. 1B, C).

Figure 2 demonstrates the type of insulitis found primarily in NZB mice over two months old (Table 1). A large area of infiltration is seen in similar location to that described above.

The type of infiltrating cells was investigated in both types of insulitis by electron microscopy. The ultrastructure of the early type of insulitis (cf. Fig. 1 A-C) is shown in Fig. 3. The majority of infiltrating cells were identified as lymphocytes and fibroblasts or fibrocytes. The destruction of islet cells in the area of infiltration was apparent (Fig. 3).

The severe type of insulitis in older NZB mice is shown in Figure 4. Infiltrates consisted predominantly of lymphocytes and macrophages. Most of the islet cells surrounding infiltrating cells are destroyed (Fig. 4). In both young and old NZB mice single lymphocytes were also found outside the main infiltration area, invading the islet tissue (Fig. 5). Only Bcells appeared to be destroyed by such lymphocytes.

$\mathrm{NZB}, \mathrm{NZB} \times \mathrm{NZW}$ and MRL mice were also investigated for infiltrates of other organs beside the pancreas. In animals of 10 weeks of age no infiltrates were observed in the lungs, liver, heart and kidney.

Sera of NZB mice were tested for autoantibodies against islet cells. We were not able to demonstrate

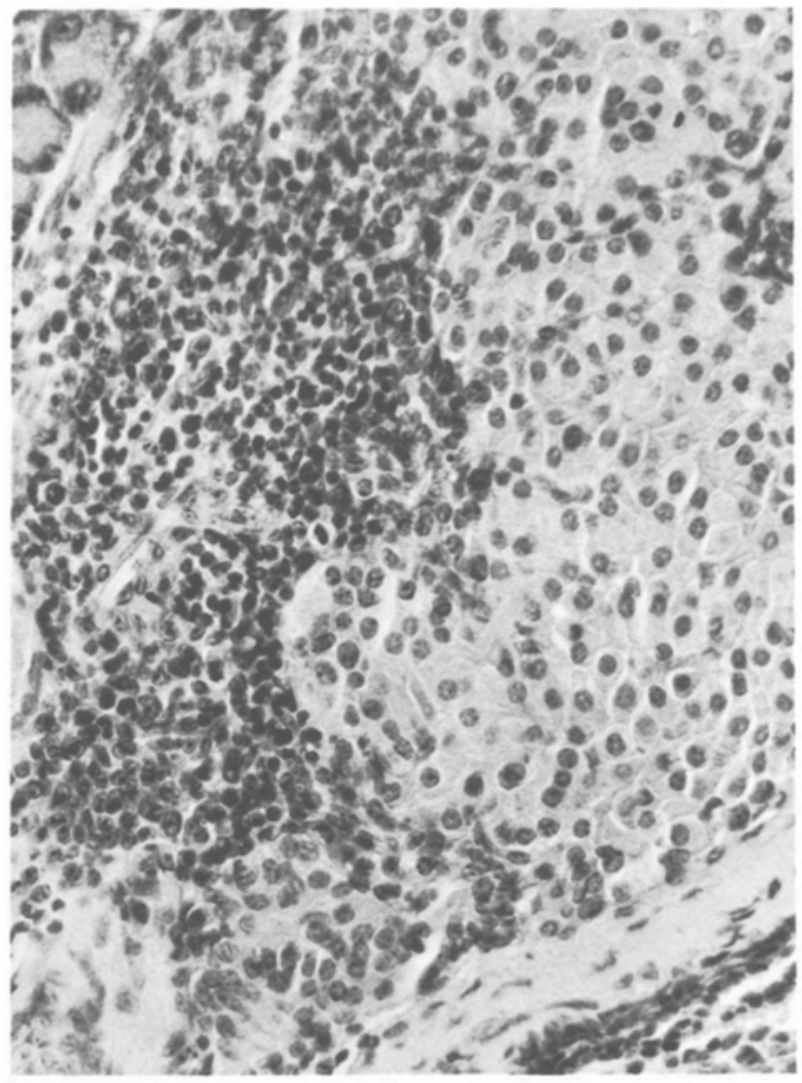

Fig. 2. Pancreatic section of a NZB/CrBomf mouse, 11 weeks of age. A large area of infiltration is seen at the ductular pole of the islet (hematoxylin-eosin, $\times 150$ )

any islet cell or islet cell surface antibodies in mice of up to 6 months of age.

Mice of the four autoimmune mouse strains and normal $\mathrm{BALB} / \mathrm{c}$ mice were subjected to a glucose tolerance test. A comparison of 10 week old mice is shown in Figure 6. The glucose tolerance of most NZB mice and of about $20-50 \%$ of NZB $\times$ NZW and MRL mice appeared abnormal, compared to BALB/ c mice. BXSB mice also showed an abnormal glucose tolerance curve in that the average blood glucose concentration was higher at $60 \mathrm{~min}$ than at $30 \mathrm{~min}$ after glucose injection. NZB and MRL had a higher initial (non-fasting) blood sugar than NZB $\times \mathrm{NZW}$, BXSB and BALB/c mice (Fig. 6).

Fig. 3 A and B. Transmission electron micrograph of a pancreatic section of a NZB/BINJ mouse, 4 weeks of age. A A cytotoxic lymphocyte (L) infiltrating the islet is seen. One B cell is lysed (LB); as can be judged from the disrupted plasma membrane (arrow) and the electronopaque plasma contrast compared to the adjacent intact B-cell $(B)$. E, Endothelial layer $(\times 13000)$. B Fibroblasts $(F)$ are found near debris of lysed islet cells. Collagen fibres $(C)$ are seen in the area of islet cell destruction $(\times 13000)$

Fig. 4. Transmission electron micrograph of a pancreatic section of a NZB/BINJ mouse, 26 weeks of age. Shown is an area of infiltration area consisting of lymphocytes (L) macrophages (MF) and lysed B-cells (LB). The macrophages have taken up debris of B-cells. The adjacent exocrine cells $(\mathrm{EX})$ are not affected $(\times 6000)$

Fig. 5. Transmission electron micrograph of a pancreatic section of a NZB/BINJ mouse, 26 weeks of age. A single lymphocyte (L) is seen expressing cytotoxic activity against adjacent B-cells (LB, lysed B-cells). Adjacent A-cells (A) and D-cells (D) remain intact ( $\times 13000)$ 

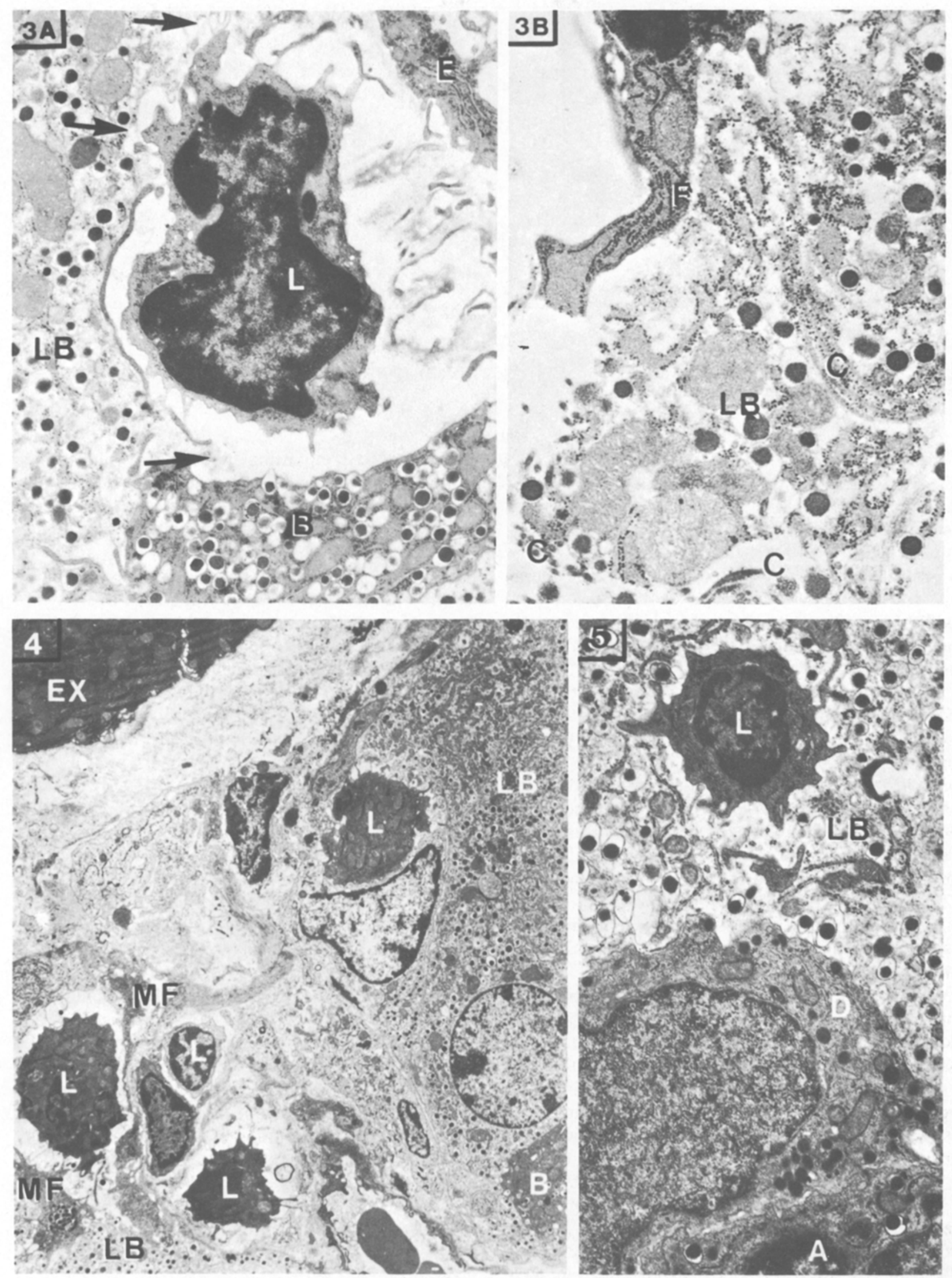


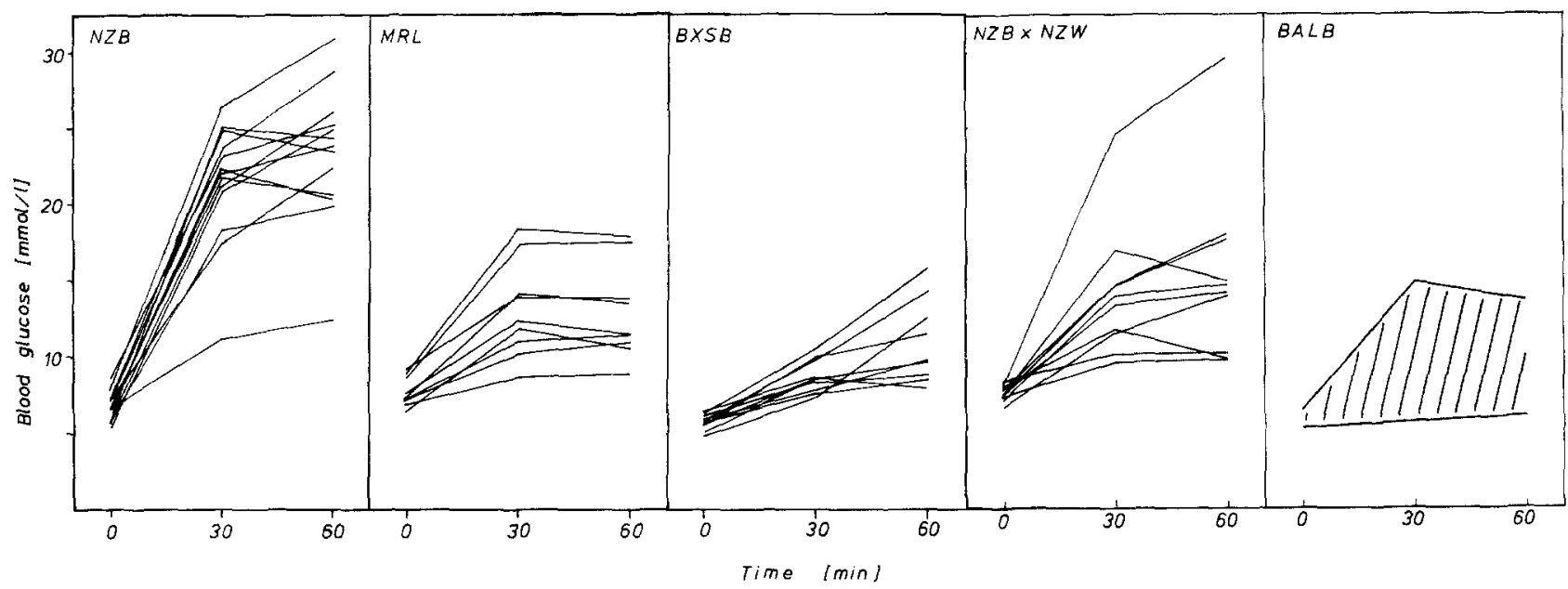

Fig. 6. Glucose tolerance tests in NZB, MRL, BXSB, NZB $\times$ NZW and normal BALB/c mice. Animals of 10 weeks of age, male and female, were compared

\section{Discussion}

Four mouse strains with lupus-like syndromes were tested in the present study for spontaneous autoimmune reactions against pancreatic islet cells. In three strains $(\mathrm{NZB}, \mathrm{NZB} \times \mathrm{NZW}, \mathrm{MRL})$ mice were found to have round cell infiltrates in their islets. As insulitis was most pronounced in NZB mice, their pancrea were chosen for ultrastructural analysis of islet histology.

Two different types of insulitis were observed. In NZB mice of up to 2 months of age infiltrates consisted of lymphocytes, fibroblasts and fibrocytes. In older mice a second type of insulitis appeared, characterized by large areas of infiltrating lymphocytes and macrophages. In both young and adult NZB mice single lymphocytes were found outside the main infiltration area. Destruction of B-cells was observed. No significant difference was seen between NZB mice of different animal colonies.

It is of interest that in all strains with insulitis the majority of infiltrating cells were localized at the ductular pole of islets, often surrounding the ductus. We have found that after transfer of insulitis with immune cells into healthy recipients, infiltration of islets also started at the ductular pole of islets (Kiesel, Freytag, Kolb, unpublished observations).

The spontaneous occurrence of autoimmune aggression against islet cells in NZB mice was restricted to cellular immune reactions. No evidence for humoral autoimmunity was found.

The observation of insulitis in strains NZB, NZB $\times$ NZW and MRL correlated with an impaired metabolic response to exogenous glucose. Almost $100 \%$ of NZB mice and $20-50 \%$ of NZB $\times$ NZW and MRL mice showed an abnormal glucose tolerance and elevated non fasting blood sugar values when compared to normal $\mathrm{BALB} / \mathrm{c}$ mice. In BXSB mice the shape of glucose tolerance curves appeared unusual in that $60 \mathrm{~min}$ glucose values were higher than 30 min values.

It is surprising to find pathological changes in the islets of 2 weeks old NZB mice, when, overt symptoms of the autoimmune disease are not observed before 2 to 3 months of age [9]. These findings indicate that infiltration of lymphocytes and fibroblasts into the islets with concomitant B-cell destruction occurs prior to the development of the lupus-like disease, with the exception of the occurrence of thymocytotoxic antibodies which have also been observed during the first month of life [10].

Mouse strains with spontaneous insulitis have not been reported so far. Natural humoral autoimmunity against islet cells, however, has been recently observed in the strain B10.BR/Sg Sn $\left(\mathrm{H}-2^{\mathrm{k}}\right)$ [8]. The presence of islet cell surface antibodies in these mice was not accompanied by pathological changes of the glucose tolerance test. Histological data on B10.BR mice were not reported.

We have presented evidence that spontaneous insulitis does occur in certain mouse strains. The relationship between lymphocytic infiltrations of the islet and the general lupus-like autoimmune disease in these strains remains unclear. Since one of the four spontaneously autoimmune strains did not show signs of pancreatic cellular autoimmunity, it may be concluded that differences exist with respect to the characteristics of immune dysfunction in the three strains. Thus, specific defects with respect to the maintenance of self tolerance towards pancreatic antigens may be assumed in NZB, NZB $\times$ NZW and MRL mice. 
Acknowledgements. The expert technical assistance of G. Dzulko, M. Grebenstein, A. Schloemer and L. Uebber is gratefully acknowledged. We thank Prof. Gries for helpful discussion and suggestions. This work was supported by the Deutsche Forschungsgemeinschaft, Sonderforschungsbereich 113, "Diabetesforschung Düsseldorf" and by the Minister für Wissenschaft und Forschung des Landes Nordrhein-Westfalen.

\section{References}

1. Craighead JE (1979) Current views on the etiology of insulindependent diabetes mellitus. N Engl J Med 299: 1439-1445

2. Rayfield EJ, Seto Y (1978) Viruses and the pathogenesis of diabetes mellitus. Diabetes 27: 1126-1142

3. Rossini AA, Like AA, Chick WL, Appel MC, Cahill GF (1977) Studies of Streptozotozin-induced insulitis and diabetes. Proc Natl Acad Sci USA 74: 2485-2489

4. Nakhooda AF, Like AA, Chappel CI, Murray FT, Marliss EB (1976) The spontaneously diabetic Wistar rat. Metabolic and morphologic studies. Diabetes 26: 100-112

5. Talal N, Steinberg AD (1974) The pathogenesis of autoimmunity in New Zealand black mice. Curr Top Microbiol Immunol 64: 79-103
6. Andrews BS, Eisenberg RA, Theofilopoulus AN, Izui S, Wilson CB, McConahey PJ, Murphy ED, Roths JB, Dixon FJ (1978) Spontaneous murine lupus-like syndromes. J Exp Med 148: $1198-1215$

7. Bottazzo GF, Doniach D, Pouplard A (1974) Islet cell antibodies in diabetes mellitus with autoimmune polyendocrine deficiencies. Lancet II: $1279-1283$

8. Kromann H, Lermark A, Vestergaard BF, Egeberg J, Nerup J (1979) The influence of the major histocompatibility complex $(\mathrm{H}-2)$ on experimental diabetes in mice. Diabetologia 16: 107-114

9. Howie JB, Helyer BJ (1968) The immunology and pathology of NZB mice. Adv Immunol 9: 21.5-266

10. Shirai T, Mellors RC (1971) Natural thymocytotoxic autoantibody and reactive antigen in New Zealand black and other mice. Proc Natl Acad Sci USA 68: 1412-1415

Received: July 16, 1979,

and in revised form: April 21, 1980

Dr. Hubert Kolb

Diabetes-Forschungsinstitut an der Universität

Auf'm Hennekamp 65

D-4000 Düsseldorf

Federal Republic of Germany 